\title{
DISCRIMINANT ANALYZES FOR THE USE OF TOBACCO, ALCOHOL AND OTHER DRUGS AMONG ADOLESCENTS IN AN URBAN CENTER IN SOUTHERN BRAZIL
}

\author{
Vagner Reinaldo Zingalli Bueno Pereira ${ }^{1}$, Jonas Michel Wolf', \\ Lucas Michel Wolf ${ }^{1}$, Gláucia Zuleide Stumm², \\ Gehysa Guimaraes Alves ${ }^{3}$, Sheila Gonçalves Câmara ${ }^{4}$
}

Clin Biomed Res. 2018;38(1):8-16

1 Programa de Pós-Graduação em Biologia Celular e Molecular aplicada à saúde, Universidade Luterana do Brasil (ULBRA). Canoas, RS, Brasil.

2 Hospital Geral de Caxias do Sul, Universidade de Caxias do Sul (UCS). Caxias do Sul, RS, Brasil.

3 Programa de Pós-Graduação em Saúde Coletiva, Universidade Luterana do Brasil (ULBRA). Canoas, RS, Brasil.

4 Curso de Psicologia, Universidade Federal de Ciências da Saúde de Porto Alegre (UFCSPA). Porto Alegre, RS, Brasil.

Corresponding author: Jonas Michel Wolf jonasmwolf@gmail.com Programa de Pós-Graduação em Biologia Celular e Molecular aplicada à saúde, Universidade Luterana do Brasil (ULBRA)

Av. Farroupilha, 8001.

92425-900, Canoas, RS, Brasil.

\section{ABSTRACT}

Introduction: The consumption of tobacco, alcohol, and illicit drugs is a problem in adolescence, especially in the school context. This study aimed to identify the demographic and social variables that distinguished the students who had used tobacco, alcohol and/or other drugs at some point of their lives from those who had never used these substances.

Methods: A school-based cross-sectional study was conducted to evaluate students attending the ninth year of elementary education in the city of Caxias do Sul $(n=1,285)$.

Results: Alcohol was the most consumed drug (74.9\%). In all the three discriminant profiles, adolescents who used tobacco throughout their lives presented more family conflict and hierarchy, higher age, greater difficulty in talking to their mother, father, and siblings, and higher school failure rates. The group that reported lifetime use of alcohol showed similar characteristics, and also reported greater loneliness. The group that has used illicit drugs was characterized, as well as other factors, by meeting with friends outside school more often, not having a good friend, being lonely, and having difficulties in talking to their father.

Conclusions: Several aspects of the social and family environment can act as factors that propitiate or distance adolescents from drugs. Public policies have a role of fundamental importance in this regard.

Keywords: Adolescents; use of drugs; family; discriminant analysis

The World Health Organization (WHO) and the Brazilian Health Ministry define adolescence as the period of life between 10 an 19 years of age $\mathrm{e}^{1,2}$. According to this definition, there are 1.8 billion adolescents worldwide ${ }^{3}$ and they account for $22.2 \%$ of the Brazilian population ${ }^{4}$. Adolescence is characterized by a natural drive towards experimentation of several activities ${ }^{5,6}$ and thus by the search for new experiences, identity, self-assertion, and individual independence ${ }^{7}$, which may lead to high health risks ${ }^{5,6}$. This stage of life represents an extremely complex period for adolescent's family and school. If adolescents are neglected by these two entities, they are expected to associate with their own social group and thus be engaged in behaviors that provide the appreciation and social approval adolescents need. Due to adolescent's developmental stage itself, such behaviors may pose risks both for adolescent's own health and for the health of others $\mathrm{s}^{6,8}$

The use of drugs, both licit and illicit, in adolescence is considered a major public health problem ${ }^{9,10}$. According to the last American report on the use of alcohol and other drugs, $26.0 \%$ of eighth-grade students and $47.0 \%$ of 12 th-grade students had used alcohol at some point of their lives. Additionally, the lifelong prevalence of tobacco use in students was of $13.3 \%$ in eighth-grade, $19.9 \%$ in 10 th-grade and $31.1 \%$ in 12th-grade. It is noteworthy that the consumption 
of any illicit drugs was of $14.8 \%, 27.9 \%$, and $38.6 \%$ in this same context, respectively ${ }^{10}$.

In Brazil, according to a research conducted by the Brazilian Center of Information on Psychotropic Drugs (Centro Brasileiro de Informações sobre Drogas Psicotrópicas, CEBRID), $25.5 \%$ of students reported to have used illicit drugs at some point of their lives, $10.6 \%$ in the last year, and $5.5 \%$ in the last month. Moreover, age at first use was mainly from 10 to 12 years ${ }^{11}$. In the capital city of the state of Rio Grande do Sul, the analysis of a sample composed of 2,052 elementary and high-school students revealed that the most used drugs over their life was cocaine and anabolic substances among boys, and amphetamines and tranquilizers among girls ${ }^{12}$. However, licit drugs, such as tobacco and alcohol, are usually the most consumed by adolescents ${ }^{10,13,14}$.

The association between school and use of tobacco, alcohol, and/or other drugs raises great concern, because it can contribute to poor school performance, greater dropout rates, and school violence $^{11,14}$. Another factor to be highlighted is the consumption of these substances at increasingly earlier ages ${ }^{14,15}$. Furthermore, alcohol use among peers may favor early sexual initiation, unwanted pregnancy, suicide, accidents, and interpersonal conflicts $^{9,14,16,17}$. In Brazil the risk factors associated with drug use have been widely studied in capital cities and metropolitan regions of different states but not in some smaller urban centers. Therefore, considering the current scenario, the present study aimed to identify the variables that distinguish adolescents who had used tobacco, alcohol, and other drugs at some point of their lives from those who had never used these substances in terms of demographic variables, school experience, family relationships, friendships, and subjective well-being among ninth year students attending public city schools in Caxias do Sul, Brazil, during the day.

\section{METHODS}

\section{Sampling}

This is a school-based cross-sectional study conducted with ninth grade students aged from 13 to 18 years attending public city elementary schools in Caxias do Sul, Brazil, during the day. This city has a population of 470,223 inhabitants, which represents the second largest population in the state, and has the third highest gross domestic product in the state. The majority of elementary school students $(72.0 \%)$ attend public city schools, followed by those attending public state schools $(28.0 \%)^{18}$.

The target population were the 3,005 ninth grade students attending the 59 public city elementary schools
(121 classes) operating in Caxias do Sul19. Sample size was calculated using Epi-Info ${ }^{\circledR}$, with a maximum tolerable error of $\pm 3 \%$ and a confidence level of $95 \%$. Thus, the initial sample size was calculated at 787 adolescents. However, assuming a design effect of 1.5, sample size was increased by 394 subjects, with a further increase of $20 \%$ of the initial sample size to compensate for losses. Therefore, sample size was estimated at 1,339 students. On average, schools had two ninth-grade classes with 23 students each. Subsequently, 64 classes were selected by systematic drawing, totaling 1,485 students. Of the 1,485 selected students, $5.4 \%$ did not participate in the study due to school refusal to participate (two schools: three classes), 5.0\% refused to answer the questionnaire, $1.5 \%$ were not allowed to participate by their parents, and $2.3 \%$ were absent on the days when the questionnaire was applied. Thus, the final sample consisted of 1,285 students, with a loss of $14.2 \%$. The present study was approved by the Research Ethics Committee of Universidade Luterana do Brasil (protocol no.: 2011,194H).

\section{Data Collection}

Data were collected using an anonymous self-administered questionnaire including 97 questions and composed of the following instruments:

1. Sociodemographic survey designed for this study: school location (urban or rural area), sex, age, and race/skin color);

2. Brazilian Economic Classification Criterion (Critério de Classificação Econômica do Brasil, CCEB), consisting of 10 questions that assess the possession of certain domestic items or services (color television, radio, bathroom, car, salaried domestic employee, washing machine, VCR and/or DVD, refrigerator, and freezer) and head-of-household educational attainment ${ }^{20}$;

3. Global School-based Students Health Survey (GSHS) developed by the WHO and adapted to Brazil. For the purposes of this study, students answered GSHS questions on the lifetime consumption of alcohol, tobacco, and illicit drugs (marijuana, anabolic substances, amphetamines, cocaine, solvents, ecstasy, and others) ${ }^{21}$;

4. Students' health behaviors were assessed considering the following blocks: a) school experience (enjoyment of school, school performance compared with classmates, and history of school failure); b) family (individuals with whom the adolescent reside, primary caregiver for most of adolescent's life, ease of communication with father, mother, and siblings); c) friends (having a 
good friend and how often the adolescent meets his/her friends outside school); d) subjective well-being (adolescent's current perception of happiness and feeling of loneliness) ${ }^{22}$;

5. Family Climate Inventory ( $\mathrm{FCl})$, developed and validated in $\mathrm{Brazi}^{23}$. The $\mathrm{FCl}$ has 22 items divided into four factors that create two different family climates: support and cohesion, which create a positive climate, and conflict and hierarchy, which create a negative climate. Total family environment scores consisted of the sum of scores for support and cohesion with the reversed scores for conflict and hierarchy. The dimension support evaluates the existence of emotional and material support given and received within the family. Family cohesion relates to the emotional bond between family members. The construct conflict assesses whether there is a critical, aggressive, and conflicting family relationship, and hierarchy is related to a clear differentiation between family members.

Study outcomes were defined as lifetime consumption of tobacco, alcohol, and other drugs. Questionnaires were administered collectively in the classroom for a mean time of 30 minutes when the teacher was absent. The informed consent form (IFC) and the instruments were administered and completed by students and were subsequently stored in different envelopes according to student's class. To collect data from absent students and/or those who forgot to bring the signed IFC, the researchers returned to schools in the weeks following the day of the main questionnaire administration. Data were collected from July to October 2011.

\section{Statistical Analyses}

Data were analyzed by the Statistical Package for the Social Sciences (SPPS) software (SPPS, Chicago, IL), version 17.0. The associations between qualitative variables and outcomes were assessed using the Pearson's chi-square test or exact Fisher's test as appropriate. The effect measure of choice was prevalence ratio $(P R)$, with a $95 \%$ confidence interval $(95 \% \mathrm{Cl})$ and a significance level of $5 \%$. Data were assessed by discriminant multivariate analysis, which identified the discriminant profiles in terms of sociodemographic variables, school experience, family relationships, relationship with friends, and well-being for each of the three study outcomes: 1) lifetime consumption of alcohol; 2) lifetime consumption of tobacco; and 3) lifetime consumption of illicit drugs. Each outcome was dichotomously evaluated as use and non-use. In this sense, we investigated the linear combinations of study factors that maximized between-group differences. This analysis was based on joint information for all variables assessed simultaneously, thus allowing for the identification of the factors that better distinguish study groups. The hypothesis testing of choice was Wilks' lambda $(\Lambda)$ (variation from zero to one) with the purpose of testing the significance of discriminant functions ${ }^{24,25}$. All analyses excluded study factors with coefficients below 0.10 , because they were little helpful in explaining between-group differences ${ }^{24}$.

\section{RESULTS}

A total of $95.2 \%$ of participants attended schools located in the urban area. More than a half $(55.0 \%)$ were female. The predominant age group was from 13 to 14 years. Most of the sample was self-reported as white $(59.3 \%)$. With regard to economic class as assessed by the CCEB, $62.3 \%$ of participants belonged to class $\mathrm{B}$. The most consumed licit drug was alcohol, with a prevalence of use of $75.5 \%$. The distribution of lifetime prevalence of use of alcohol, tobacco, and other drugs according to sociodemographic variables showed a significant difference only for the variable age. Age from 15 to 16 years was associated with use of tobacco $(p<0.001 ; P R=1.70)$ and of other drugs $(p=0.005 ; P R=2.20)$ (Table 1$)$.

The three discriminant functions obtained in this study were significant for lifetime use of tobacco $(\Lambda=0.85 ; p<0.001)$, alcohol $(\Lambda=0.89 ; p<0.001)$, and other drugs $(\Lambda=0.92 ; p=0.002)$ (Table 2). With regard to the correct classification of cases into their groups of origin, the discriminant functions correctly classified $80.9 \%, 75.3 \%, 94.5 \%$ of cases of lifetime use of alcohol, tobacco use, and other drugs, respectively.

Table 3 shows the variables that were included in the discriminant function to distinguish adolescents that had used tobacco at some point of their lives and those who had not. Tobacco users exhibited greater family conflict and hierarchy, were older, had greater difficulty in talking to their mother, father, and siblings and a greater number of failed grades, met friends outside school more often, and felt lonely more often. Conversely, variables that better distinguished adolescents who had never smoked were study in rural area, non-white self-reported skin color, greater school enjoyment, positive perception of school performance compared with classmates, greater feeling of happiness, and greater family cohesion and support.

Discriminant analysis of alcohol use showed that students who consumed it were distinguished by their greater age, greater difficulty in talking to their mother and father about topics of interest, greater family conflict 
Table 1: Crude analysis of consumption of tobacco, alcohol and other drugs among students.

\begin{tabular}{|c|c|c|c|c|c|c|c|c|c|c|}
\hline \multirow[b]{2}{*}{ Variables } & \multirow[b]{2}{*}{$\begin{array}{c}n \\
(\%)\end{array}$} & \multicolumn{3}{|c|}{ Tobacco } & \multicolumn{3}{|c|}{ Alcohol } & \multicolumn{3}{|c|}{ Other drugs } \\
\hline & & n $(\%)^{*}$ & $\begin{array}{c}\text { PR } \\
(95 \% \mathrm{Cl})\end{array}$ & $\mathbf{p}$ & n (\%)* & $\begin{array}{c}\text { PR } \\
(95 \% \mathrm{Cl})\end{array}$ & p & n $(\%)^{*}$ & $\begin{array}{c}\text { PR } \\
(95 \% \mathrm{Cl})\end{array}$ & p \\
\hline \multicolumn{11}{|c|}{ School location } \\
\hline Urban area & $\begin{array}{l}1223 \\
(95.2)\end{array}$ & $\begin{array}{c}268 \\
(22.0)\end{array}$ & $\begin{array}{c}1.03 \\
(0.6-0.53)\end{array}$ & \multirow{2}{*}{0.52} & $\begin{array}{c}908 \\
(74.4)\end{array}$ & 1.00 & \multirow{2}{*}{0.50} & $\begin{array}{c}63 \\
(5.2)\end{array}$ & $\begin{array}{c}3.15 \\
(0.4-0.53)\end{array}$ & \multirow{2}{*}{0.17} \\
\hline Rural area & $\begin{array}{c}62 \\
(4.8) \\
\end{array}$ & $\begin{array}{c}13 \\
(21.3) \\
\end{array}$ & 1.00 & & $\begin{array}{c}46 \\
(75.4) \\
\end{array}$ & $\begin{array}{c}1.01 \\
(0.8-0.53)\end{array}$ & & $\begin{array}{c}1 \\
(1.6) \\
\end{array}$ & 1.00 & \\
\hline \multicolumn{11}{|l|}{ Sex } \\
\hline Male & $\begin{array}{c}578 \\
(45.0)\end{array}$ & $\begin{array}{c}122 \\
(21.2)\end{array}$ & 1.00 & \multirow{2}{*}{0.63} & $\begin{array}{c}427 \\
(74.3)\end{array}$ & 1.00 & \multirow{2}{*}{0.46} & $\begin{array}{c}34 \\
(5.9)\end{array}$ & $\begin{array}{c}1.38 \\
(0.8-0.53)\end{array}$ & \multirow{2}{*}{0.11} \\
\hline Female & $\begin{array}{c}706 \\
(55.0) \\
\end{array}$ & $\begin{array}{c}159 \\
(22.6) \\
\end{array}$ & $\begin{array}{c}1.06 \\
(0.8-0.53)\end{array}$ & & $\begin{array}{c}526 \\
(74.6) \\
\end{array}$ & $\begin{array}{c}1.00 \\
(0.9-0.53)\end{array}$ & & $\begin{array}{c}30 \\
(4.3) \\
\end{array}$ & 1.00 & \\
\hline \multicolumn{11}{|l|}{ Age } \\
\hline $13-14$ years & $\begin{array}{c}957 \\
(75.1)\end{array}$ & $\begin{array}{c}180 \\
(18.9)\end{array}$ & 1.00 & \multirow{3}{*}{$<0.01$} & $\begin{array}{c}698 \\
(73.1)\end{array}$ & 1.00 & \multirow{3}{*}{0.04} & $\begin{array}{c}37 \\
(3.9)\end{array}$ & 1.00 & \multirow{3}{*}{$<0.01$} \\
\hline $15-16$ years & $\begin{array}{c}305 \\
(23.9)\end{array}$ & $\begin{array}{c}97 \\
(32.1)\end{array}$ & $\begin{array}{c}1.70 \\
(1.3-0.53)\end{array}$ & & $\begin{array}{c}240 \\
(78.9)\end{array}$ & $\begin{array}{c}1.08 \\
(1.0-0.53)\end{array}$ & & $\begin{array}{c}26 \\
(8.6)\end{array}$ & $\begin{array}{c}2.20 \\
(1.3-0.53)\end{array}$ & \\
\hline $17-18$ years & $\begin{array}{c}13 \\
(1.0)\end{array}$ & $\begin{array}{c}4 \\
(30.8) \\
\end{array}$ & $\begin{array}{c}1.63 \\
(0.7-0.53)\end{array}$ & & $\begin{array}{c}12 \\
(92.3) \\
\end{array}$ & $\begin{array}{c}1.26 \\
(1.1-0.53)\end{array}$ & & $\begin{array}{c}1 \\
(7.7)\end{array}$ & $\begin{array}{c}1.98 \\
(0.2-0.53)\end{array}$ & \\
\hline \multicolumn{11}{|c|}{ Race/skin color } \\
\hline White & $\begin{array}{c}761 \\
(59.3)\end{array}$ & $\begin{array}{c}161 \\
(21.2)\end{array}$ & 1.00 & \multirow{2}{*}{0.25} & $\begin{array}{l}577 \\
(76.0)\end{array}$ & $\begin{array}{c}1.05 \\
(0.9-0.53)\end{array}$ & \multirow{2}{*}{0.06} & $\begin{array}{c}37 \\
(4.9)\end{array}$ & 1.00 & \multirow{2}{*}{0.45} \\
\hline Non-white & $\begin{array}{c}522 \\
(40.7) \\
\end{array}$ & $\begin{array}{c}119 \\
(23.0)\end{array}$ & $\begin{array}{c}1.08 \\
(0.8-0.53)\end{array}$ & & $\begin{array}{c}375 \\
(72.1)\end{array}$ & 1.00 & & $\begin{array}{c}27 \\
(5.2)\end{array}$ & $\begin{array}{c}1.03 \\
(0.7-0.53)\end{array}$ & \\
\hline \multicolumn{11}{|c|}{ Brazilian Economic Classification Criterion } \\
\hline Class A & $\begin{array}{c}17 \\
(1.4)\end{array}$ & $\begin{array}{c}2 \\
(11.8)\end{array}$ & 1.00 & & $10(58.8)$ & 1.00 & & $\begin{array}{c}1 \\
(5.9)\end{array}$ & $\begin{array}{c}1.84 \\
(0.2-0.53)\end{array}$ & \multirow{4}{*}{0.17} \\
\hline Class B & $\begin{array}{c}770 \\
(62.3)\end{array}$ & $\begin{array}{c}170 \\
(22.2)\end{array}$ & $\begin{array}{c}1.88 \\
(0.5-0.53)\end{array}$ & \multirow{2}{*}{0.40} & $\begin{array}{c}580 \\
(75.5)\end{array}$ & $\begin{array}{c}1.28 \\
(0.8-0.53)\end{array}$ & & $\begin{array}{c}46 \\
(6.0)\end{array}$ & $\begin{array}{c}1.87 \\
(1.0-0.53)\end{array}$ & \\
\hline Class C & $\begin{array}{c}439 \\
(35.5)\end{array}$ & $\begin{array}{c}95 \\
(21.7)\end{array}$ & $\begin{array}{c}1.84 \\
(0.4-0.53)\end{array}$ & & $\begin{array}{c}323 \\
(73.7)\end{array}$ & $\begin{array}{c}1.25 \\
(0.8-0.53)\end{array}$ & 0.27 & $\begin{array}{c}14 \\
(3.2)\end{array}$ & 1.00 & \\
\hline Class D+E & $\begin{array}{c}10 \\
(0.8)\end{array}$ & $4(40 \%)$ & $\begin{array}{c}3.40 \\
(0.7-0.53)\end{array}$ & & $6(60.0)$ & $\begin{array}{c}1.02 \\
(0.5-0.53)\end{array}$ & & $\begin{array}{c}2 \\
(20.0)\end{array}$ & $\begin{array}{c}6.25 \\
(1.6-0.53)\end{array}$ & \\
\hline
\end{tabular}

*Totals do not coincide due to missing information for some variables. PR: Prevalence ratio; $95 \% \mathrm{Cl}: 95 \%$ confidence interval.

Table 2: Eigenvalue, percentage of explained variance, and level of significance of discriminant functions for the outcomes lifetime use of tobacco, alcohol, and other drugs.

\begin{tabular}{ccccccc}
\hline Discriminant function & Eigenvalue & $\begin{array}{c}\text { Explained } \\
\text { variance }\end{array}$ & $\begin{array}{c}\text { Wilks' } \\
\text { lambda }\end{array}$ & Chi-square & df & p-value \\
\hline Tobacco (lifetime use/non-use) & 0.348 & $100 \%$ & 0.85 & 98.75 & 27 & $<0.001$ \\
Alcohol (lifetime use/non-use) & 0.119 & $100 \%$ & 0.89 & 72.06 & 26 & $<0.001$ \\
Other drugs (use/non-use) & 0.083 & $100 \%$ & 0.92 & 51.26 & 26 & 0.002 \\
\hline
\end{tabular}

df: degrees of freedom.

and hierarchy, greater number of failed grades, and greater frequency of loneliness. Students who had never used alcohol were distinguished by their greater current feeling of happiness, greater school enjoyment, greater current feeling of happiness, positive perception of school performance compared with classmates, ease of communication with friends about topics of interest, greater family support and cohesion, and greater psychological well-being (Table 4).
Discriminating functions for students who had used illicit drugs were older age, greater number of failed grades, meeting friends outside school more often, not having a good friend, feeling lonely more often, greater difficulty in talking to father about topics of interest, having greater family conflict and hierarchy. Students who had never used illicit drugs distinguished by greater school enjoyment, greater ease in talking to friends about topics of internet, 
Table 3: Demographic variables, school experience, family relationships, relationships with friends, and subjective well-being that were included in the discriminant function to distinguish students who had used tobacco at some point of their lives from those who had not.

\begin{tabular}{lc}
\hline \multicolumn{1}{c}{ Variables } & Function \\
\hline School enjoyment & 0.498 \\
Negative family environment - conflict & -0.456 \\
Current subjective feeling of happiness & 0.430 \\
Perception of school performance & 0.399 \\
compared with classmates & \\
Age & -0.390 \\
Ease/difficulty in talking to mother about & -0.343 \\
topics of interest & \\
Ease/difficulty in talking to father about & -0.313 \\
topics of interest & \\
Feeling lonely & -0.311 \\
School failure & -0.274 \\
Frequency of meeting friends outside & -0.255 \\
school & \\
Positive family environment - cohesion & 0.235 \\
Number of failed grades & -0.229 \\
Positive family environment - support & 0.211 \\
Ease/difficulty in talking to siblings about & -0.183 \\
topics of interest & \\
Race/skin color & 0.161 \\
School location (urban or rural area) & 0.146 \\
Negative family environment - hierarchy & -0.128 \\
\hline
\end{tabular}

greater family cohesion, and greater feeling of happiness (Table 5).

\section{DISCUSSION}

The most used drug was alcohol, with a prevalence of $75.5 \%$, followed by tobacco and illicit drugs. Alcohol

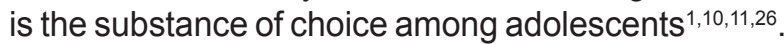
Data from the CEBRID revealed a higher prevalence than that of the present study, reaching $89.1 \%$ in some regions ${ }^{11}$. Additionally, greater frequency of consumption of this substance was found in the Brazilian state of São Paulo $(88.0 \%)^{26}$ and in other countries like Germany $(90.0 \%)^{27}$ and the USA $(80.0 \%)^{28}$. Similar percentages were reported in the city of Belo Horizonte $(74.2 \%)^{15}$ and Porto Alegre $(73.0 \%)^{29,30}$, whereas other locations in Brazil showed a lower, but not less important, prevalence $(50.0 \%)^{14}$. An interesting hypothesis proposes that these differences in the prevalence of alcohol use may be especially explained by cultural factors, since alcohol is socially accepted and starts being consumed mainly with family and friends ${ }^{13,14,31}$. These behaviors, which are accepted by friends, family and parents, have a multiplying effect on the use of other substances, such as tobacco In this study
Table 4: Demographic variables, school experience, family relationships, relationships with friends, and subjective well-being that were included in the discriminating function to distinguish students who had used alcohol at some point of their lives from those who had not.

\begin{tabular}{lc}
\hline \multicolumn{1}{c}{ Variables } & Function \\
\hline Current subjective feeling of happiness & -0.498 \\
School enjoyment & -0.435 \\
Ease/difficulty in talking to mother about & 0.426 \\
topics of interest & \\
Ease/difficulty in talking to father about & 0.345 \\
topics of interest & \\
Negative family environment - conflict & 0.330 \\
Ease/difficulty in talking to friends about & -0.300 \\
topics of interest & \\
Perception of school performance & -0.297 \\
compared with classmates & \\
Feeling lonely & 0.294 \\
Positive family environment - cohesion & -0.240 \\
Psychological well-being & 0.232 \\
Positive family environment - support & -0.192 \\
Age & 0.189 \\
School failure & 0.171 \\
Negative family environment - hierarchy & 0.163 \\
Having a good friend currently & 0.163 \\
Number of failed grades & 0.154 \\
Frequency of meeting friends outside & 0.113 \\
school & \\
\hline
\end{tabular}

Table 5: Demographic variables, school experience, family relationships, relationships with friends, and subjective well-being that were included in the discriminant function that distinguishes students who had used illicit drugs at some point of their lives from those who had not.

\begin{tabular}{lc}
\hline \multicolumn{1}{c}{ Variables } & Function \\
\hline School enjoyment & -0.491 \\
Current subjective feeling of happiness & -0.392 \\
Frequency of meeting friends outside & 0.384 \\
school & \\
Age & 0.373 \\
Number of failed grades & 0.351 \\
Negative family environment - conflict & 0.317 \\
History of school failure & 0.297 \\
Feeling lonely & 0.253 \\
Having a good friend currently & 0.250 \\
Ease/difficulty in talking to friends about & -0.221 \\
topics of interest & \\
Positive family environment - cohesion & -0.216 \\
Negative family environment - hierarchy & 0.207 \\
Ease/difficulty in talking to father about & 0.159 \\
topics of interest & \\
\hline
\end{tabular}

tobacco use showed a prevalence of $21.9 \%$ and was greater than that observed in Brazil (16.0\%). Moreover, similar frequencies were reported in the 
cities of Porto Alegre (25.3\%) and Curitiba (25.1\%) whereas lower frequencies were found in the city of Florianópolis $(15.0 \%)^{11}$. An hypothesis for the high rates obtained in this study may be the lack of programs to prevent the use of both licit and illicit drugs in school curricula ${ }^{32}$, lack of family support for not using tobacco ${ }^{31}$, and lack of a harmonious family environment ${ }^{33,34}$.

With regard to the lifetime use of other drugs, the present study identified a prevalence of $5.0 \%$. This result is similar to that of a study assessing 23 cities of four Brazilian regions that found an overall prevalence of $4.0 \%$ and of $6.0 \%$ for southern Brazil ${ }^{35}$. However, this percentage was different from that of the study conducted by Malta et al..$^{15}$, who found that the reported lifetime use of illicit drugs among students was $7.3 \%$, and from CEBRID data, which found a prevalence of lifetime use of drugs of up to $33.0 \%{ }^{11}$. In this scenario, it should be highlighted that CEBRID data cover Brazilian state capitals and often do not represent other cities. Age was the only demographic variable that exhibited significant differences in the use of tobacco, alcohol and other drugs among the study population. Prevalence rates indicate that the use or possibly the experimentation of tobacco and other drugs occur from 15-16 years of age. Conversely, the use of alcohol and other drugs was associated with age from 16-17 years. Some studies $^{10,11,13,16,36}$ reported that alcohol and tobacco experimentation occurred at younger ages compared with the present study. However, the consumption of tobacco, alcohol, and other drugs increases with age, thus corroborating our findings $\mathrm{s}^{15,37}$.

An analysis of the discriminant profiles for each outcome reveals that the use of both licit and illicit drugs was associated with family variables. Studies conducted in Brazil associated use of alcohol with a conflicting family environment ${ }^{13}$ and use of tobacco and illicit drugs with dissatisfaction, lack of support, and family conflicts ${ }^{13,38,39}$. In other contexts worldwide an association was found between use of substances and lack of family affective bonds ${ }^{39,40}$. Adolescents who use substances have greater difficulties in communicating with family ${ }^{39,40}$. In this sense, there is evidence that families with difficulty in communicating and establishing rules increase the risk for drug use among adolescents ${ }^{41}$. Furthermore, our data reveal a negative family environment, mainly characterized by conflict and hierarchy, less cohesion, and less support for the prevention of tobacco and alcohol consumption. With regard to the association between family functioning and drug use among adolescents, it was found that some family-related aspects, such as family conflicts and less family cohesion, were associated with drug use among adolescents ${ }^{13,42}$.
Additionally, risk factors included lack of support and respect among family members, intrafamilial violence, lack of boundaries, and poor family bonds ${ }^{13,38}$. Lack of affection and confidence between parents and children creates poor family relationships, favoring adolescent's indiscipline and involvement with alcohol and drugs ${ }^{43}$.

Discriminant school-related aspects are also the same in the three profiles, with school enjoyment being the variable with the greatest discriminant power for the use of tobacco and other drugs and the second most important discriminant variable for the use of alcohol. These findings were similar to those of previous studies ${ }^{34}$. Adolescents who used drugs reported less school enjoyment and a greater number of failed grades ${ }^{15,44-46}$. Perception of school performance was worse in those who consumed tobacco and alcohol compared with abstainers. The relationship between low school performance or school dropout is recurrently discussed in the literature ${ }^{46,47}$.

Relationship with friends have a greater discriminant for the use of alcohol and other drugs. In the three discriminant profiles, substance users were distinguished by meeting friends out of school more often. Having a good friend and having great difficulty in talking to friends about topics of interest were also found to be discriminant variables for the use of alcohol and other drugs. A study conducted by Vasters and Pillon ${ }^{47}$ on the use of illicit drugs observed that adolescents were usually accompanied by one or several friends or by relatives at the time of first experimentation. This finding reveals drug use is strongly influenced by the social group and sometimes the family $y^{7,13,17,47}$. One of the major factors for adolescent drug use is having friend who use drugs, which generates peer pressure $^{17,48}$. Conversely, family, friends, and school are constantly communicating among themselves; therefore, the balance between these elements promotes the protection against drug consumption ${ }^{39}$.

As for subjective well-being, feeling of happiness appears to have high discriminant power in the three profiles, being the one with the greatest discriminant power for alcohol use, the second most discriminant variable for the use of other drugs, and the third most discriminant variable for tobacco use, showing that adolescents who use legal and illegal drugs experience less feeling of happiness. It is important to emphasize that the main reason for adolescents to consume alcohol, tobacco and/or other drug is becoming more sociable and extroverted in order to facilitate social interactions ${ }^{49}$. That said, it is assumed that the use of licit and/or illicit drugs increases detection and perception of happiness at the time of use; however, this feeling is reduced during abstinent periods ${ }^{49}$, which 
is consistent with findings from the present study. Subjective well-being or happiness is understood as a combination of positive mood and absence of negative mood conditions such as anxiety and depression. With respect to drug use, some aspects were reported by adolescents as factors that increase the desire to use drugs, including feelings of anger, loneliness, and being accompanied by friends who use drugs ${ }^{17,47}$. Loneliness is also present in the three discriminant profiles that characterize adolescents who use drugs. Happiness or positive mood are associated with being loved, having friends, and engaging in social activities. These variables have an impact on health by promoting happiness and may often be part of the chain of events associated with drug use. Conversely, factors like loneliness and depressive symptoms are associated with well-being and use of drugs ${ }^{17}$. In our study, the profile that distinguishes adolescents who use alcohol also included worse psychological well-being. Smoking and alcohol intake have already been associated with low psychological well-being ${ }^{36}$.

Sociodemographic variables have greater discriminant power for tobacco use. Age was the only variable that was present in the three profiles, with older age being a discriminant factor for substance use. A study conducted in the city of Cuiabá found an association between older age and greater frequency of tobacco experimentation ${ }^{50}$. Within this context, ethnicity and household location were also considered as discriminant factors. Discriminant analysis showed that adolescent smokers are distinguished by being self-reported as white and study in the urban area. In the study by Malta et al. ${ }^{15}$, which evaluated capital cities of all Brazilian states and the Federal District, African and indigenous ethnicity was associated with use of licit and illicit drugs. Significant differences were also observed between adolescents who studied in urban and rural areas with regard to the use of illicit drugs, with urban areas exhibiting the highest prevalence rates. It is noteworthy that the discrepancies between studies may result from sociodemographic and cultural characteristics of each sample and from methods to analyze, measure, and classify the study variables. Finally, the scenario described by the data obtained in this study may generate hypotheses for the development of public policies to raise students and their family awareness and aimed at minimizing the devastating social effects of drugs use.

\section{CONCLUSIONS}

This study allowed us to identify the several family, school, and psychological aspects associated with the use of alcohol, tobacco, and illicit drugs. Future research should conduct discriminant analyses in other regional settings in Rio Grande do Sul and Brazil to better understand this highly relevant issue for the society.

\section{Conflicts of Interest}

The authors declare no conflicts of interest.

\section{REFERENCES}

1. Monteiro MG. Alcohol y salud pública en las Américas: un caso para la acción. Washington: Organização Pan-Americana de Saúde; 2007. [cited 2017 Jan 16]. Available from: http://www.who.int/substance_abuse/ publications/alcohol_public_health_ americas_spanish.pdf

2. Sei MB, Zuanazzi AC. A clínica psicanalítica com adolescentes: considerações sobre a psicoterapia individual e a psicoterapia familiar. Psicol Clin. 2016;28:89-108.

3. Gupta M, Engelman R, Levy J, Luchsinger G, Merrick T, Rosen J. The power of 1.8 billion adolescents, youth and the transformation of the future. New York: United Nations Population Fund; 2014. [cited 2016 Jan 16]. Available from: https://www. unfpa.org/sites/default/files/pub-pdf/ EN-SWOP14-Report FINAL-web.pdf
4. Instituto Brasileiro de Geografia e Estatística (IBGE). Projeções e estimativas da população do Brasil e das Unidades da Federação. Brasília: IBGE; 2017. [cited 2017 Jan 16]. Available from: http://www.ibge.gov.br/ apps/populacao/projecao/

5. Bava S, Tapert SF. Adolescent brain development and the risk for alcohol and other drug problems. Neuropsychol Rev Clin. 2010;20:398413.

6. Skala K, Walter H. Adolescence and alcohol: a review of the literature. Neuropsychiatr. 2013;27:202-11.

7. Almeida RMM, Trentini LB, Klein LA, Macuglia GR, Hammer C, Tesmmer M. Uso de álcool, drogas, níveis de impulsividade e agressividade em adolescentes do Rio Grande do Sul. Psico. 2014;:45:65-72.
8. Bonilla Castillón CE. La dinámica de la violencia escolar y su relación con la interacción familiar: una mirada desde los adolescentes escolarizados. Redes. 2016;33:53-66.

9. United Nations Office On Drugs and Crime (UNODC). Referências ao Brasil OMS. Vienna: UNODC; 2013. World Drug Report 2013. [cited 2017 Jan 16]. Available from: http:// www.unodc.org/documents/lpobrazil/Topics_drugs/WDR/2013/PTReferencias_BRA_Portugues.pdf

10. Johnston LD, O'Malley PM, Miech RA, Bachman JG, Schulenberg JE. Monitoring future national survey results on drug use 19752015: overview, key findings on adolescent drug use. Ann Arbor: Institute for Social Research, The University of Michigan; 2016. [cited 
2017 Jan 16]. Available from: http:// www.monitoringthefuture.org/pubs/ monographs/mtf-overview2015.pdf

11. Carlini EA. VI levantamento nacional sobre o consumo de drogas psicotrópicas entre estudantes do ensino fundamental e médio das redes públicas e privadas de ensino nas 27 capitais brasileiras. São Paulo: Centro Brasileiro de Informações sobre Drogas Psicotrópicas; 2010. [cited 2017 Jan 16]. Available from: http://www.antidrogas.com.br/ downloads/vi_levantamento.pdf

12. Galduróz JCF, Noto AR, Fonseca AM, Carlini EA. V levantamento nacional sobre o consumo de drogas psicotrópicas entre estudantes do ensino fundamental e médio das redes públicas e privadas de ensino nas 27 capitais brasileiras 2004. São Paulo: Unifesp; 2005. [cited 2017 Jan 16]. Available from: http:// www.cebrid.com.br/wp-content/ uploads/2004/04/V-LevantamentoNacional-sobre-o-Consumo-deDrogas-Psicotr\%C3\%B3picasentre-Estudantes-do-Ensino Fundamental-e-M\%C3\%A9dio-daRede-P\%C3\%BAblica-de-Ensino-nas27-Capitais-Brasileiras-2004.pdf

13. Reis TG, Oliveira LC. Pattern of alcohol consumption and associated factors among adolescents students of public schools in an inner city in Brazil. Rev Bras Epidemiol. 2015;18:13-24.

14. Elicker E, Palazzo LS, Aerts DRGC, Alves GG, Câmara S. Use of alcohol, tobacco and other drugs by adolescent students from Porto VelhoRO, Brazil. Epidemiol Serv Saude. 2015;24:399-410.

15. Malta DC, Mascarenhas MDM, Porto DL, Duarte EA, Sardinha LM, Barreto $\mathrm{SM}$, et al. Prevalência do consumo de álcool e drogas entre adolescentes: análise dos dados da Pesquisa Nacional de Saúde Escolar. Rev Bras Epidemiol. 2011;14:136-46.

16. Abreu MNS, Souza CF, Caiaffa WT. Tabagismo entre adolescentes e adultos jovens de Belo Horizonte, Minas Gerais, Brasil: influência do entorno familiar e grupo social. Cad Saude Publica. 2011;27:935-43.

17. Giatti IL, Campos MO, Crespo CD, Andrade SSCA, Barreto SM. Trabalho precoce, marcador de vulnerabilidades para saúde em escolares brasileiros: Pesquisa
Nacional de Saúde do Escolar (PeNSE 2012). Rev Bras Epidemiol. 2014;17(supl 1):1-14.

18. Rio Grande do Sul. Secretaria da Educação. Porto Alegre: Secretaria da Educação do Rio Grande do Sul; 2017 [cited 2017 Jan 16]. Available from: http://www.educacao.rs.gov.br/buscade-escolas

19. Caxias do Sul. Secretaria Municipal da Educação. Comunicação de Despacho $n^{\circ}$ 675/2010. Caxias do Sul; 2010.

20. Associação Brasileira de Empresas de Pesquisa (ABEP). Critérios de Classificação Econômica Brasil. São Paulo: ABEP; 2017. [cited 2017 Out 20]. Available from: http://www.abep. org/criterio-brasil

21. Vieria PC, Aerts DRGC, Freddo SL, Bittencourt A, Monteiro L. Uso de álcool, tabaco e outras drogas por adolescentes escolares em município do Sul do Brasil. Cad Saude Publica. 2008;24:1-12.

22. Aarø LE, Wold B, Kannas L, Rimpela M. Health Behaviour in Schoolchildren: a WHO cross national survey: a presentation of philosophy, methods and selected results of the first survey. Health Promot. 1986;1:1733.

23. Teodoro MLM, Allgayer M, Land B. Desenvolvimento e Validade fatorial do Inventário do Ambiente familiar (IFC) para adolescentes. Psicol Teor Prat Pública. 2009;11:27-39.

24. Field A. Discovering statistics using IBM SPSS. 4th ed. London: SAGE Publications; 2009.

25. Mello GR, Macedo FQ, Tavares F Fo, Slomski V. Identificando o endividamento dos estados brasileiros: uma proposta através de análise discriminante. Enfoq Reflex Cont. 2006;25:5-14.

26. Locatelli D, Sanchez Z, Opaleye $M$, Carlini C, Noto A. Influências socioeconómicas no padrão de consumo de álcool entre estudantes de escolas privadas em São Paulo. Rev Bras Psiquiatr. 2012;34:193-200.

27. Donath C, Grässel E, Baier D, Pfeiffer C, Karagülle D, Bleich S, et al. Alcohol consumption and binge drinking in adolescents: comparison of different migration backgrounds and rural vs. urban residence-a representative study. BMC Public Health. 2011;11:84.
28. Swendsen J, Burstein M, Case B, Conway KP, Dierker L, He J, et al. Use and abuse of alcohol and illicit drugs in US adolescents: results of the National Comorbidity SurveyAdolescent Supplement. Arch Gen Psychiatry. 2012;69:390-8.

29. Nardi FL, Jahn GM, Dell'Aglio DD. Perfil de adolescentes em privação de liberdade: eventos estressores, uso de drogas e expectativas de futuro. Psicol Rev. 2014;20:116-37.

30. Willhelm AR, Cabral JCC, Steiger JO, Silva JFF, Ugarte LM, Almeida RMM. Consumo de álcool na adolescência e relação com uso excessivo de bebidas alcoólicas dos pais: estudantes de quatro escolas de Porto Alegre. Psico Porto Alegre. 2015;46:208-16.

31. Jinez MLJ, Souza JRM, Pillon SC. Uso de drogas e fatores de risco entre estudantes de ensino médio. Rev Lat Am Enfermagem. 2009;17:246-52.

32. Pereira APD, Paes AT, Sanchez ZM. Factors associated with the implementation of programs for drug abuse prevention in schools. Rev Saude Publica. 2016;50:1-10.

33. Medeiros KT, Maciel SC, de Sousa PF, Tenório-Souza FM, Dias CCV. Representações sociais do uso e abuso de drogas entre familiares de usuários. Psicol Estud. 2013;18:26979.

34. Barroso T, Mendes A, Barbosa A. Analysis of the alcohol consumption phenomenon among adolescents: study carried out with adolescents in intermediate public education. Rev Lat Am Enfermagem. 2009;17:347-53.

35. Câmara MM, Tambellini AT, RoselliCruz A. Trabalho abuso de drogas e os aparelhos ideológicos de Estado: um estudo com alunos do ensino médio e fundamental. Physis Rev Saúde Coletiva. 2010;20:219-34.

36. Bertoni N, Bastos FL, Mello MB, Makuch MY, Sousa MH, Osis MJ, et al. Uso de álcool e drogas e sua influência sobre as práticas sexuais de adolescentes de Minas Gerais, Brasil. Cad Saude Publica. 2009;25:1350-60.

37. Barbosa M, Carlini-Cotrim B, Silva-Filho A. O uso de tabaco por estudantes de primeiro e segundo graus em dez capitais brasileiras: possíveis contribuições da estatística 
multivariada para compreensão do fenômeno. Rev Saude Publica. 1989;23:401-9.

38. Zamberlan M, Freitas MG, Fukamori L. Relações pais e filhos adolescentes e estratégias de prevenção de riscos. Paidéia. 1999;9:35-49.

39. Ruiz MR, de Andrade D. La familia y los factores de riesgo relacionados con el consumo de alcohol y tabaco en los niños y adolescentes (Guayaquil-Ecuador). Rev Lat Am Enfermagem. 2005;13:813-8.

40. Yen JY, Yen CF, Chen CC, Chen $\mathrm{SH}, \mathrm{Ko} \mathrm{CH}$. Family factors of internet addiction and substance use experience in Taiwanese adolescents. Cyberpsychol Behav. 2006;10:523-9.

41. Pratta EMM, Santos MA. Reflexões sobre as relações entre drogadição, adolescência e família: um estudo bibliográfico. Estud Psicol. 2006;11:315-22.
42. Musitu G, Jiménez TI, Murgui S. Funcionamiento familiar, autoestima y consumo de sustancias en adolescentes: un modelo de mediación. Salud Publica Mex. 2007:49:3-10.

43. Schenker M, Minayo MCS. A implicação da família no uso abusivo de drogas: uma revisão crítica. Cien Saude Colet. 2003;8:299-306.

44. Souza CC, Oliveira MS. Transtorno de déficit de atenção/hiperatividade em adolescentes usuários de drogas. Arq Bras Psiquiatr Neurol Med Legal. 2005;99:10-7.

45. Simões C, Matos MG, Batista-Foguet J. Saúde e felicidade na adolescência: factores individuais e sociais associados às percepções de saúde e de felicidade dos adolescentes portugueses. Rev Bras Ter Cogn. 2008;4:19-38.
46. Cardoso LRD, Malbergier A. Problemas escolares e o consumo de álcool e outras drogas entre adolescentes. Psicol Esc Educ. 2014;18:27-34.

47. Vasters GP, Pillon SC. O uso de drogas por adolescentes e suas percepções sobre adesão e abandono de tratamento especializado. Rev Lat Am Enfermagem. 2011;19:317-24.

48. Pechansky F, Szobot CM, Scivoletto S. Uso de álcool entre adolescentes: conceitos, características epidemiológicas e fatores etiopatogênicos. Rev Bras Psiquiatr. 2004;26:14-7.

49. Walter NT, Mutic S, Markett S, Montag C, Klein AM, Reuter M. The influence of alcohol intake and alcohol expectations on the recognition of emotions. Alcohol Alcohol. 2011;46:680-5.

50. Silva MP, Silva RMVG, Botelho C. Fatores associados à experimentação do cigarro em adolescentes. J Bras Pneumol. 2008;34:927-35.

Received: Nov 03, 2017 Accepted: Jan 09, 2018 